DOI : $10.14746 / \mathrm{pp} .2015 .20 .4 .15$

\title{
Jan KVĚTINA
}

Department of Political Science at the Faculty of Arts, Charles University in Prague

\section{Polish Aristocratic Identity as a Discourse of Ideology: A Critical Discourse Analysis Approach*}

\begin{abstract}
Critical discourse analysis (CDA) can be considered the contemporary, dominant approach to the study of national identity, which presupposes that a nation is an imagined community which is produced and reproduced discursively. Moreover, CDA denies the traditional dichotomy between political and cultural nations, which is viewed solely as a purpose-built consequence of power. With regard to the fact that most researchers who use CDA limit their approaches to the modern context of the $20^{\text {th }}$ century, it is desirable to ask to what extent one can apply methods of CDA to pre-modern national identities. The clarification of this issue should be deemed the main aim of this study, which holds that the Polish aristocratic nation is a convenient case for this kind of research, because its elites had to reflect not only the loss of statehood, and thus the programme of future desired development, but also the causes of previous failure. The analysis of the conflicts between conservative national attitudes during the $19^{\text {th }}$ century should therefore define who was considered a Pole and to what extent national identity was based on ideological and discursive assumptions.
\end{abstract}

Key words: Critical Discourse Analysis, Polish identity, conservatism, nationalism, constructivism

$\mathbf{T}$ his paper aims to present and analyse one of the ways in which national identity especially historical identity in our case - can be interpreted discursively. To do this, it is necessary to specify the method of Critical Discourse Analysis (CDA), because it is deemed a relatively new approach whose identification may be unclear. This statement can be supported by the fact that what CDA is and what it is not is often the subject of much debate, since some authors tend to treat so-called Foucaultian Discourse Analysis (Peräkyla, 2005) separately, whereas others implicitly understand the approaches inspired by Foucault as an inherent part of CDA (Fairclough, 1992, p. 37-61).

Bearing these ambiguities in mind, it is desirable to state some key attributes that further clarify what one means when speaking about the way CDA is applied to the issue of national consciousness. With regard to this application, it is necessary to reflect mainly on the works of Norman Fairclough and Ruth Wodak, being considered the most influential thinkers on CDA: Fairclough is mentioned because he can be labelled as the main initiator of this approach, and Wodak because she applied CDA to the question of national identity, which is the main issue of this paper. Hence, if necessary to use a CDA approach for the research of historical identity in the Polish environment, it is worth noting that this method presupposes that:

1) Discourse is considered not just as a system of communication which delimits space for actual statements, but, after Foucault, as a structure of meaning, or

* Artykuł zostal napisany w ramach projektu badawczego "Podstawowa literatura przedmiotu a kształt współczesnej politologii. Political science, Politische Wissenschaft i politologija w ujęciu porównawczym" (2012/05/B/HS5/00597), finansowanego przez Narodowe Centrum Nauki. 
even more as the "ways of constituting knowledge, together with the social practices, forms of subjectivity and power relations which inhere in such knowledge and relations between them" (Weeden, 1987, p. 108). That means that CDA in this respect overshadows the study of linguistic elements, or rather uses the study of language for revealing the real contexts and meanings of speech.

2) Discourse is taken neither strictly as a reflection of materialistic relations of production, nor as the only level of social reality, but as an irreducible part of social life (Foucault, 2002, p. 24) where it is necessary to distinguish between the discursive elements standing for speech acts creating meanings and non-discursive aspects (Fairclough, 2001, p. 122-123). However, it would be wrong to understand this difference as a gap between abstract and non-existing traits on the one hand and reality on the other, because CDA supposes that there is a strong interdependency between discursive and non-discursive acts, where the language of the discourse formulates a social system and keeps it running, and social system provides space and acts which must be interpreted through the discourse (Wetherell, 2001, p. 390-392; Wodak, 2009, p. 9). As Uri Ram claims in connection with the relationship between discourse and national identity: "the fact that nationality is a story does not challenge its reality, because myths are not mystifications" (Ram, 1994, p. 154).

3) Discourse is strongly oriented towards the research of power, which means that CDA tries to identify the power content of speech acts by revealing how the seemingly neutral denominations of social facts are used to shape social values and society itself. For that reason, CDA is viewed as a subversive approach, for it can show the arbitrariness and calculated essence of the pillars of social reality - those pillars seen by traditional approaches as stable and natural ones. Hence, most researchers using CDA admit their normative and emancipatory aims that entail supporting those who are oppressed and excluded (Wodak, 2009, p. 9), although, at the same time, they try to claim that their research should be viewed as a contribution to universal knowledge (Wodak, 2001, p. 93). This can be summed up as follows: if one manages to prove that some components of society are just a part of the dominant power construction, it is necessary to lay down some alternative options, meant to show that changes are possible and required.

As we have just specified the key features of CDA in connection with upcoming application of this method to the main issue of this paper, it is also time to draw our attention to the question of national identity, which is one of the most frequent problems studied by CDA. Also, it is necessary to highlight some essential principles concerning the possibilities and difficulties of studying national consciousness.

As we have claimed that discourse creates distinguishable and, according to the ontology of constructivists, also very real social objects, as Foucault showed in the example of madness (Foucault, 2006) - we can assume that both national objects and subjects do not come into being until they are created through textual or speech acts. That means that there is neither an essence of national identity nor national actors (meaning bearers of this national identity) before the collective consciousness, as Wodak claims: "we assume that nations are mental constructs, 'imagined communities', which nationalised political subjects perceive as discrete political entities. Secondly, we assume that national identities, 
as special forms of social identities, are produced and reproduced, as well as transformed and dismantled, discursively" (Wodak, 2009, p. 3-4).

The absence of anything that could be classified as an essential national identity forces CDA to assume that all nation-building processes are based on some kind of negative delimitation. This means that if you are creating the concept of your identity, you are not able to identify what you are, until you identify what you are not - the meaning of your national identity comes into being when you delimitate it against different concepts. This Heraclitean principle of national identity is especially apparent with Wodak, claiming that: "in imagining national singularity and homogeneity, members of a national community simultaneously construct the distinctions between themselves and other nations, most notably when the other nationality is believed to exhibit traits similar to those of one's own national community" (Wodak, 2009, p. 4). At the same time, it implies that there is no single national identity as such according to CDA, but there is a complex of competing conceptions that all the time clash with one another in everyday speech acts: "there is - in an essentialist sense - no such thing as one national identity... we believe rather that different identities are discursively constructed according to audience, setting, topic and substantive content... national identities are therefore malleable, fragile and, frequently, ambivalent and diffuse" (Wodak, 2009, p. 4).

Moreover, this refutation of a single national identity is linked to the crucial rejection of the traditional dichotomy between so-called political and cultural nations, commonly seen as a classical part of the theory of nationalism based on the concept of Friedrich Meinecke (Hroch, 2009, p. 18). His influential work, which has been widely accepted and served as an explanatory model for the differences between Western and Eastern European nations, presupposes that there have been two basic ways of nation-building processes: either the national society identifies itself primarily with the political structure, or with ethnic and cultural bonds (Meinecke, 1908). On the contrary, Wodak, using the CDA approach, denies this clear and strict dichotomy when she claims that no nation is entirely political or cultural and, instead of identifying whole nations in this way, it should be emphasised that this dichotomy is present in one nation as a tool of power and as an ideological clash among different concepts: "discourses of national identity constructed by residents of any given state will always contain or imply both cultural and political elements... the principal reason to maintain the distinction is to highlight differences in national self-perception within a country - be it between different political or ideological camps or even within one and the same political group" (Wodak, 2009, p. 5).

If we look thoroughly at the application of CDA to the research into national identity, we can claim that these efforts have thus far always had something in common, as their intention has been narrowed to its display in a modern environment - this means that, for example, the approach of Wodak tries to capture the narrative of Austrian national identity during the $20^{\text {th }}$ and $21^{\text {st }}$ centuries (Wodak, 2009). However, if one supposes that national identity represents - which means that it has always represented and still represents - a practice which can be experienced through discourse, it is inevitable to ask to what extent it is possible to analyse the problem of the interdependency between national categories and power relations in pre-modern times, when the national concept had to compete with other kinds of identity such as those of estates, religion, local patriotism, etc. 
It is obvious that in that case one has to face some serious difficulties, as it is not possible to apply CDA in all its complexity. There is apparently no space for its emancipatory nature anymore, because the identification of historical power relations has a minimal impact on contemporary power structures. If there is a proof that Polish aristocratic identity was maintained discursively by certain actors, the validity of the CDA approach will be confirmed, even though its historicity does not have any normative consequences. There is also a limited number of discursive acts that can be analysed. As modern CDA uses many textual and speech sources, such as internet forums or sociological surveys researching the opinions of mass populations, research into national identity before the information revolution is limited mainly to the textual expressions of the elites, such as philosophical works, pamphlets, correspondence, newspaper articles, etc.

However, despite all these difficulties, I am convinced it is desirable to analyse historical nation-building process through CDA, especially in the Polish case, because it can be regarded as a unique example whose original aristocratic identity was interrupted very suddenly and violently by the ending of an independent state. Under these circumstances, when elites had to adapt their social positions to the norms of the ruling powers, as seen, for instance, in the barefoot gentry that was not regarded as a noble estate anymore, the national discourse represented one of the main symbolic tools of how to maintain or change the Polish social system. Thus, after 1795 two questions with ideological connotations became fundamental for the Polish national narrative, and these can be interpreted as a paraphrase of Porter's article ${ }^{1}$ (Porter, 1992):

1) What is the Polish nation and what is its essence in terms of its existence?

2) Who are the Poles?

It is worth noting that Polish ideological and political movements in the $19^{\text {th }}$ century are traditionally seen as a priori categories, which means that some objective materialist facts are assumed to exist, being classified as causes of different political concepts. ${ }^{2} \mathrm{Nev}-$ ertheless, the application of the CDA approach to this question brings some extensions or rather modifications of this standpoint with the implementation of the discursive level, which tries to show that the competing concepts of Polish nation did not stem purely from distinct economic and political interests, but were also co-determined by the negative textual and speech delimitation of their own principles against the others. In this respect, it is necessary to answer the following questions:

A) Is it possible to interpret Polish aristocratic identity as a myth which became a symbol of a discursive clash between competing political groups, and which was adapted by them according to their interests and needs?

B) Are we allowed to claim that Polish conservative, nationalistic, socialist and other concepts of the nation were formed discursively in order to confirm the validity of distinct ideological postulates, which means - along with the aforementioned Heraclitean principle of CDA - that the core of national identity was

${ }^{1}$ Brian Porter entitled one of his articles about the policy of the National Democratic Party "Who is a Pole and where is Poland?", which sounds more than fitting, because each political movement struggling for its concept of Polish development had to clarify these questions.

${ }^{2}$ For results of these objectivist approaches regarding Polish national identity see, for example, Ludwikowski, 1991 or Bromke, 1967. 
created primarily by negative delimitation against competing concepts, because it became meaningful purely through this negation?

There are many national concepts in the Polish context of the $19^{\text {th }}$ century that could serve as a verification of this theoretical assumption, however, the concept dealing with the dichotomy between the two conservative_notions of national identity should be mentioned as one of the most convenient ones, traditionally termed as the clash between true and false conservatism (Ludwikowski, 1991, p. 47-49).

This denotation comes from the works of A. Z. Helcel ${ }^{3}$ and later L. Górski, who tried to define the main differences between two distinct ideas of conservative thinking. Helcel's work Aforyzmy o prawdziwym i falszywym konserwatyzmie (Helcel, 2009, p. 1-5) is traditionally believed to be a philosophical reflection, specifying and considering the real differences between his own understanding of conservative thinking and the ideas of Henryk Rzewuski ${ }^{4}$ who represented its counterpart. However, taking critical discourse analysis into account, it is possible to understand this dichotomy as a discursive tool of a political clash whose main aim was to defeat the opponent, which becomes more apparent when we realise that both concepts of conservative national identity make sense only by comparison with its alternative. The concept of conservatism can be thus described as a floating signifier following the concept of Ernest Laclau (Laclau, 1996), because its content is dependent on the necessity of both thinkers to deny the principles of the opposing one.

When one tries to decide whether the clash between Helcel and Rzewuski should be read as a philosophical dispute, or rather as part of a power discourse which forced them to advocate the genuineness of their approaches and label themselves as the flag-bearers of the only true conservatism, it is desirable to focus on their definition of the principle of conservatism. The desire for preservation is usually the only part of conservative ideology which can be regarded as a common and unifying feature of all conservative thinkers, irrespective of their historical, cultural and temporal context. It is not so surprising that comparing various concepts of conservatism in different countries can be both very confusing and controversial, because something that is seen as a valuable traditional heritage in one country can be assessed as dangerous and revolutionary change in another. To put it briefly, the relationship of an American Conservative in the $19^{\text {th }}$ century towards individual freedom was completely contradictory to the evaluation of the same principle by a Russian supporter of conservatism in the same era, because their concepts of traditions were entirely different and the only thing they had in common was their conviction to preserve something (Pipes, 2005, p. xii).

However, when looking at the case of Polish conservatism, one can work out that even this simple and seemingly indispensable part of conservative thinking is not so clear-cut anymore. When Helcel tries to distinguish his "genuine" conservatism from the "false" one, he denies that a conservative should be someone who impulsively conserves every-

\footnotetext{
${ }^{3}$ Antoni Zygmunt Helcel (1808-1870) was one of the leading figures of the Polish conservative movement in Austrian Partition, where he acted as a legal historian, politician and political thinker.

${ }^{4}$ Henryk Rzewuski (1791-1866) was a Polish novelist and thinker who belonged to a famous family of magnates of the First Polish-Lithuanian Commonwealth. He influenced Polish conservative movement. especially by his specific genre of aristocratic novels called "gawędy". The most famous of them, The Memoirs of Soplica, is considered to be one of the main inspirations for Pan Tadeusz by Adam Mickiewicz.
} 
thing at any cost, because in that case one might consider even those revolutionaries who struggle for the preservation of revolutionary values as conservatives (Helcel, 2007, p. 2). Hence, he claims that the essence of traditional values is more important than the process of preservation itself, which means that a genuine conservative is someone who is able to explain the reasons for their conservatism, whereas a false one tries to maintain anything, just because they are too comfortable and lazy to change their way of life: "[j] ust as frugality doesn't order you to spare everything, but to spare reasonably, conservatism orders you the same... the relationship of frugality towards avarice is the same as an attitude of real conservatism towards a false one" (Helcel, 2007, p. 2). It is obvious that Helcel tries to interpret this rivalry between both concepts of conservatism as the antagonism between rationalism and irrationalism or fanaticism; this shows, therefore, an important reason why the false concept should be rejected. However, if we turn to the statements of Rzewuski, we discover that the question of rationality and irrationality is more puzzling than Helcel tried to persuade us to believe.

Rzewuski reads the distinction entirely differently, for he does not criticise the difference between the essence and process of preservation. Instead, he emphasises that a proper conservative should be determined to defend his beliefs even if it is not convenient, and thus he must also reject all proposals to betray his consciousness by looking for compromises. Again, in this case one can demonstrate that Rzewuski does not espouse a neutral philosophical discourse, but tries to undermine a competing conservative stream by criticising Helcel's willingness to act as an arbiter of various social interests and to harmonise them. Rzewuski denotes this approach as a cardinal weakness, because meanwhile "all the power of revolutionaries consists of their conviction that there is nothing in common between their ideas and principles of conservatism" (Ludwikowski, 1991, p. 57), those conservatives who delude themselves that compromise is possible merely weaken their positions in favour of their rivals, because they are not able to understand that their competition is a zero-sum game - you either win or lose. Moreover, one should notice that, having stated this, Rzewuski refuted Helcel's scheme of rationality against irrationality, because he was able to support his own conservative beliefs by reasonable arguments as Helcel requires. His promoted understanding of conservatism has nothing in common with the fanatical effort to preserve all the things of the past, since Rzewuski argues consistently and sceptically that political conflict should be read as an unceasing clash of distrust. Moreover, he also reverses this dichotomy by claiming that irrational conservatives are those who try to adapt their solutions to liberal ones and, hence, act naively and irrationally. Thus, one can conclude that both Helcel and Rzewuski use denunciative speech acts, which is apparent when they try to establish a dichotomy between rationality and irrationality. This means that they both use such words that create the notion that only their attitude can be supported by rational arguments, while the opposite concept must be rejected as irrational. It is therefore obvious that these terms of rationality and irrationality are senseless if they stand alone and can be grasped only if they are interpreted discursively as a result of a mutual power conflict.

Another inherent part of the conservative doctrine, which proves to be purpose-built and a rhetorical feature of the aforementioned competition, can be labelled the concept of the natural order whose principles were created by God, and so representing the historical and supra-individual essence of human society. Rzewuski writes about the necessity of 
interpersonal mutuality and dependency in this respect, as he is not willing to admit that man can exist for himself. Only if he is embodied in hierarchical bonds, such as those between a ruler and his subject, a landowner and his serf or between state and its citizen (Ludwikowski, 1991, p. 80-81), can he be described as a part of humanity - thus there is no space for individualism. The main collective identity is represented by a national community described by Rzewuski as the sum of fundamental laws manifesting itself in national wisdom, national consciousness and national belief. One should notice that his attention was not on a state structure, but on a national society which he understands as an a priori entity, established with a mission that must be fulfilled. It is, therefore, apparent that a true conservative should appreciate the nation more than the state, because states can be destroyed, but nations can keep performing their duties even without them.

Even in this case there is a strong similarity to Helcel's point of view calling for the primary and independent origin of society when he rejects the idea that the state should be regarded as a source of positive human values: "[i]s it the state which gives us all benefits and life? Is the state the highest and ultimate goal of man? No, the state does not form marriages, nor families, the state does not give birth to a man, it cannot replace physical or intellectual work, it doesn't create matter for preserving life, till soil, seize natural wealth or augment our possessions... it cannot give physical strength nor health, nor spiritual power, nor honesty, piety or genius..." (Helcel, 2007, p. 3). All these social phenomena, such as rights and duties of family, ownership or religious belief thus stem not from the state, but from a free society where God's intention manifests itself. However, the fact that the state is not an original essence but a derived structure does not undermine its authority. According to Helcel, this is necessary for the protection of those principles that are so indispensable for maintaining the conservative character of society.

Hence, one may claim that although the state does not come directly from God and can be viewed as a social product, there is a strong difference from the liberal point of view, because Helcel as a conservative believes that the state should serve as a tool which helps a nation to fulfil those aims that were ascribed to it by God. This understanding of the state structure is obviously far removed from the concept of the voluntary social contract, which is meant to protect the individual interests of its members, because, on the contrary, it should embody the natural tendency for a hierarchical order and social organisation. This is described by Helcel as social harmony, ensuring a balanced relationship between the individual and the whole, just as much as between two individuals: "there is no government without power, no order without government, and without order it is not possible to unite the parts together... there is no society without order and without society no human can exist" (Helcel, 2007, p. 5). It implies that if God creates man as a social being in the Aristotelian sense, it is necessary to respect the state as a divine product, even though it was established artificially, because it reflects the original purpose of the national collective identity and social hierarchy.

This actually means that the ideas of Helcel can be compared to those of Rzewuski, even if they both tried to prove the contrary. Although they use a different mode of argumentation, they are similarly convinced of the necessity of hierarchical bonds as a social expression of God's purpose. This similarity is especially obvious when one takes into account Helcel's promoted distinction between rationalism and fanaticism, which seems to be mistaken. Both versions of conservatism were able to support their claims by ratio- 
nal arguments, so that they similarly supposed there were some questions beyond the scope of the human mind which have to be solved not by reason but by belief. It shows us again that it is fully legitimate to emphasise the existence of a strong conservative tradition which rejected the rationalist cult of liberalism, but at the same time one must admit that it is extremely difficult, or even confusing to distinguish various conservative doctrines from one another. With regard to the important traits of society they were both blurred and interchangeable, which means that Helcel's distinction should be considered more as wishful-thinking than reality.

Moreover, there is another level of the aforementioned dispute that should be considered by means of the analysis of ideological-based speech acts. When Helcel criticises Rzewuski, he does not limit his rejection to the alleged irrationalism of his counterpart, but he also tries to persuade us that "false conservatism" cannot be even regarded as a collection of ideas, because it does not represent any coherent belief based on sincerity and moral standards, and thus should be assessed as merely a façade of selfish interests. This accusation results from the statement upon which conservatives should act as agents of a particular social class. This belief was frequently emphasised by Rzewuski, who was willing to appreciate the merits and possibilities of the nobility, which he took as the "main advocates of national spirit: there would be no genius in society without a nobility, as the nobility represents the essence of national heritage" (Rzewuski, 1851, p. 182). One cannot ignore the fact that Rzewuski, who was strongly influenced by his French idol Joseph de Maistre in this respect (Lytkowski, 1925), admired his own social class very uncritically, but, on the other hand, it would be unfair to read this approach purely as a purpose-built aspiration for a nobleman's favour, because this would lead to omitting some important points of Rzewuski's argumentation.

One should notice that his belief about the leading role of the nobility among other social classes as a part of Divine Providence is coherent with his concept of the European nations' purposes. In this regard, he wanted to demonstrate that all the ancient nations created by God were established with some particular mission which must be fulfilled during their existence as "every nation is an emanation of a moral principle which it is devoted to" (Rzewuski, 1851, p. 108). It is evident that Rzewuski tried to define all these principles in particular nations, and thus he proclaimed that the French were born to lead other nations, the German spirit should reveal the truth, and Italians should represent beauty and the English utility (Rzewuski, 2003, p. 11). The Polish spirit was, according to him, made for sacrificing itself in the struggle for freedom, which was not unusual in the Polish historical context of the $19^{\text {th }}$ century, because the identification of national identity with universal freedom stemmed from the strong messianist character of Polish philosophical movements of that time ${ }^{5}$ (Walicki, 1991). Although it might be surprising that even conservatives were able to understand specific traditions as a part of global tendency, Rzewuski's universalist approach is highly important for the explanation of his admiring attitude towards his own social class. One should realise that the development

\footnotetext{
${ }^{5}$ Although some kind of universal messianist tendencies can possibly be traced in every political movement of that time, it is obvious that the most sophisticated concept, which was later developed by others, was that of Mickiewicz.
} 
of Polish society was read by Rzewuski as a sign of decadence and not as evolution, which means that each change prevents Poles from being able to fulfil their historical task, because if they were created as defenders of certain values they would have to remain the same. As the most valuable summary of Polish ancient principles, Rzewuski refers to the so-called golden freedoms which were represented by the promotion of noble privileges and by the individual and egalitarian essence of the aristocratic ethos. That means that, according to him, Polish nobles were obliged to protect their privileges not only to maintain their individual freedom, but also to preserve their constitution, because without it they would not be able to live as they should, and they would even endanger their identity: "our constitution is the most appropriate for a nation which has been chosen to devote itself to the fight for freedom of the world... and it also prevents us from ceasing to be Poles" (Rzewuski, 2003, p. 18).

Under these circumstances, one should accept that when Helcel blamed "false conservatives" for being selfish and for ignoring any principled underpinnings, he misinterpreted the point probably because he wanted to discredit his rival. It is possible to accept the statement that Rzewuski defended the doctrine of a certain social class, but it is important to highlight that he was also able to explain his motives by theoretical argumentation with the greater good. Moreover, if we look at Helcel's works more carefully, we can find that his concept of conservatism is strongly determined by the prism of aristocratic values as well, which is apparent, for example, when he expresses his disregard or even disgust for the lowborn classes. He criticises the temperament of rough peasants (Pl. chtopi), which he evaluated as the nature of "inborn communists who regard the land and forests as an indivisible divine gift for all people, such as water and air" (Helcel, 2007, p. 99) and he is convinced that for those peasants work does not mean a way to develop oneself, but is merely a tool to satisfy their addiction to vodka. However, this contempt is not limited only to the serfs, because Helcel was also very critical of other untitled classes, such as the bourgeoisie, who he assessed as decadent due to their materialism. Moreover, he explains his mistrust towards non-nobles by their insufficient education, which means that they are so often and easily affected and persuaded by the Jews who "demoralise the lower classes of Christian society and lead them to drunkenness... they corrupt officials and force the youth into usury" (Helcel, 2007, p. 102).

If Rzewuski takes the view that those classes which do not respect aristocratic authority cannot belong to the nation, he expresses nearly the same attitude as Helcel does. This is further evident when Rzewuski tries to prove that the peasants have no national spirit due to their opposition to the natural order, which results in their need to be led by those who have those qualities - i.e. the nobles. This idea is actually very similar to Helcel's archetype of the enlightened patriotic landowner who should decide the fate of the Polish nation and even the lowborn classes as a reasonable and educated father protecting them from the danger of the Jews.

However, this shows us that there is one important, distinctive line which has not been created solely by discursive acts, but determined by competing character of both thinkers, and which thus can be regarded as a real difference. This is neither the scale of rationalism nor the absence of universal ideas as Helcel promotes, but the different understanding of the chosen class which should act as saviour of the nation. If we accept the aforementioned thesis about the importance of nobility, it is necessary to notice that Helcel strictly 
differentiates between the wealthy aristocracy and the so-called barefoot gentry. He opposes the traditional Polish principle that "a noble in his manor is equal to a voivode" 6 (Helcel, 2007, p. 107) and appreciates the richer members of the noble estate for their reliable Catholic attitudes and consistent rituals: "religious spirit is more developed among the higher and better nobility... there is a strong variety in the case of the lower nobility" (Helcel, 2007, p. 108). Now it is fully understandable why Helcel supported the reform movement that tried to remove some traditional principles of the Polish political system during the second part of the $18^{\text {th }}$ century, because their members were convinced of the necessity of such steps to save their homeland. Although Helcel's appreciation may be surprising, if one realises that he emphasised the continuity of social norms, it is necessary to take into account that not only did reformers promote radical changes such as freedom of speech or division of power, but they also called for a hereditary monarchy, or argued that poor gentry should have their political rights removed. This part of the reforms represented the desired course for Helcel, because the political destruction of lower nobility would have strengthened the positions of the wealthy magnates - those noblemen who were born to protect and save all classes, according to him.

At this point it is possible to view Rzewuski's conservatism as a genuine power counterpart of the concept of Helcel, because the first called for maintaining all the traditional political principles which were read as guardians of the golden freedoms of nobles and their national mission. This means that Rzewuski promoted the equality of all noble estates, regardless of their property, and the elective monarchy as well, because only these institutions could ensure that petty nobles would remain decisive agents among all citizens. He also tried to support his statement, using his own interpretation of national history, which was meant to demonstrate that any attempts to reform the state had been rightly punished, because these reforms did not respect the essence of the national spirit. The failure of the Polish state at the end of the $18^{\text {th }}$ century could be therefore explained as a just act of Providence which had to punish Polish citizens for losing their national pride (Rzewuski, 1851, p. 262). According to Rzewuski, they risked it when they accepted the pernicious reforms espoused, among others, by Helcel, and that is why divine purpose was forced to demonstrate all the horrors caused by the danger of the principle of popular sovereignty (Ludwikowski, 1991, p. 64-65).

Actually, this situation seems highly paradoxical; where a more extreme conservative approach is represented by a demand for a wider scope of individual freedom and equality, which again proves that there is no universal or objective concept of conservatism, because all these concepts must be taken as floating signifiers expressing discursive and power rivalries. This shows us that although both concepts try to prove that there is a real and important difference from each other, they use the same arguments, which means that they are distinct primarily on the discursive level of speech acts and not in connection with their desired goals. Both conservative principles of national identity promote the same existence of natural laws, they identically argue for the collective nature of the individual man, they agree that there are some principles which cannot be understood by hu-

\footnotetext{
${ }^{6}$ This is a rhyming phrase which sounds really poetically in Polish: "szlachcic na zagrodzie równy wojewodzie".
} 
man reason because they were created by God. Thus, although both these doctrines are composed of irrational traits, they use their alleged rationality as the main argument against each other - one can therefore say that rationality, as the mythical essence of both concepts, is created discursively and antagonistically while, at the same time, there is no possibility of defining the rational extent of the first doctrine without the other. Moreover, a similar distinction is present when both authors try to blame each other that the opposite way of thinking is not a coherent doctrine, but only serves as a purpose-built advocacy of a certain social class. Again in this case, they are similar to each other, because both these concepts arise from power structures and represent the interests of the noble class, but neither of them is willing to admit it and establish their own sense on the assumption that, whereas we defend important and eternal principles, our competitors are merely protecting their own interests.

There are many related issues concerning historical Polish identity which should be analysed using CDA. One of the most important research tasks could, for example, verify the thesis that it is not possible to distinguish between political and cultural nations, as we have already mentioned, following the principle of CDA (Wodak, 2009, p. 5). In this regard, the distinct approach of the National Democrats led by R. Dmowski, who was able to modify their concept of national spirit according to their actual needs and the context in which they used their arguments against the socialists, conservatives and other ideological rivals, should be a primary object of further research. If one wants to decide whether adherents of the ND espoused the political or cultural principles of the nation, one is forced to admit that their notion of it was constantly changing, because again their concept was a purpose-built construct without any unambiguous criteria. The decision of who is, or is not a Pole was left entirely up to the National Democrats themselves, which is made especially apparent by introducing their concept of a national spirit: "we are a nation due to our feeling of unity, because we share a common consciousness, common national spirit... which has been created over centuries... and whose common will is legitimised by a national purpose that we all are aware of" (Dmowski, 1895). One of the fundamental questions that has yet to be answered is the ambivalent approach of the ND party, containing a lot of abstract and symbolic figures of speech, that enabled them to exclude or include all the national minorities according to how much the party profited from it.

That is why they were able to accept a Lithuanian identity (Balicki, 1908, p. 49; Wapiński, 1977, p. 230) while refusing Ukrainians, who were labelled as "a dark nationality, which is unmannered and greedy and, therefore, it is necessary to use violence against it" (Piątkowski, 1966, p. 51) or Belarusians: "as for Belarusians, nobody can deny that they are just a tribe and not a nation" (Dmowski, 1901, p. 618) and thus to advocate their concept of Polish imperialism.

It is self-evident that this issue must be studied by means of a CDA approach more thoroughly, and some further research can thus be based on this draft. However, to put it shortly, there is no ultimate answer as to whether national democrats defined the nation politically or culturally, and, similarly, there is no such answer to the difference between the two competing doctrines of conservatism; as seen in both cases, the construction and reconstruction of discursive acts was crucial, since all the agents involved tried to define their own principles by denying the opposite concepts. 


\section{Bibliografia}

Balicki Z. (1908), Egoizm narodowy: wobec etyki, nakł. Towarzystwa Wydawniczego, Lwów.

Bromke A. (1967), Poland's Politics: Idealism vs. Realism, Harvard University Press, Cambridge-Massachusetts.

Dmowski R. (1895), "Przegląd Wszechpolski“, no 1.

Dmowski R. (1901), "Przegląd Wszechpolski“, no 10.

Fairclough N. (1992), Discourse and Social Change, Polity Press, Cambridge.

Fairclough N. (2001), Critical discourse analysis as a method in social scientific research, in Methods of Critical Discourse Analysis, eds. R. Wodak, M. J. Meyer et al., Sage, London.

Foucault M. (2002), Archaeology of knowledge, Routledge, London-New York.

Foucault M. (2006), History of Madness, Routledge, London-New York.

Helcel A. Z. (2009), O prawdziwym i falszywym konserwatyzmie, in: Wybór pism, ed. W. Kozub-Ciembroniewicz, Ośrodek Myśli Politycznej Księgarnia Akademicka, Kraków.

Hroch M. (2009), Nảrody nejsou dílem nảhody. Přciciny a pr̃edpoklady utvárení moderních evropskích národu, SLON, Praha.

Laclau E. (1996), Emancipation(s), Verso, London.

Ludwikowski R. R. (1991), Continuity and Change in Poland: Conservatism in Polish Political Thought, Catholic University of America Press, Washington D.C.

Lytkowski J. (1925), Józef de Maistre a Henryk Rzewuski. Studium porównacze, Skład główny w Kasie im. J. Mianowskiego, Kraków.

Meinecke F. (1908), Weltbürgertum und Nationalstaat: Studien zur Genesis des deutschen Nationalstaates, R. Oldenbourg, München-Berlin.

Peräkylä A. (2005), Analyzing talk and text, in: The Sage Handbook of Qualitative Research, eds. N. K. Denzin, Y. S. Lincoln et al., Sage, London.

Ram U. (1994), Narration, Erziehung und die Eifindung des jüdischen Nationalismus, Österreichische Zeitschrift für Geschichtswissenschaft, vol. 5, no 2.

Rzewuski H. (1851), Wędrowki Umystowe, in: Pisma Henryka hrabi Rzewuskiego, vol. 2, B. M. Wolff, Petersburg.

Rzewuski H. (2003), Uwagi o dawnej Polsce przez starego Szlachcica Seweryna Soplice Cześnika Parnawskiego napisane 1832 roku, eds. P. Dudziak B. Szleszyński, Fundacja Akademia Humanistyczna, Warszawa.

Pipes R. (2005), Russian Conservatism and Its Critics. A Study in Political Culture, Yale University Press, New Haven-London.

Porter B. (1992), Who is a Pole and Where is Poland? Territory and Nation in the Rhetoric of Polish National Democracy before 1905, "Slavic Review", vol. 51, no 4.

Piątkowski W. (1966), Idee spoleczno-polityczne "Polaka" (1896-1906). Przyczynek do ksztaltowania sie ideologii Narodowej demokracji, "Rocznik Historii Czasopiśmiennictwa Polskiego", vol. 5, no 2 .

Walicki A. (1991), Trzy patriotyzmy. Trzy tradycje polskiego patriotyzmu i ich znaczenie wspótczesne. Res Publica, Warszawa.

Wapiński R. (1977), Idea narodu w myśli spolecznej i politycznej endecji przed rokiem 1918, in: Idee i koncepcje narodu w polskiej myśli politycznej czasów porozbiorowych, eds. J. Goćkowski.

A. Walicki, Państwowe Wydawnictwo Naukowe, Warszawa.

Weeden C. (1987), Feminist Practice and Poststructuralist Theory, Basil Blackwell, Oxford.

Wetherell M. (2001), Debates in Discourse Research, in: Discourse Theory and Practice. A Reader, eds. M. Wetherell, S. Taylor, S. J. Yates et al., Sage, London. 
Wodak R., De Cilla R., Reisigl M., Liebhart K. (2009), The Discursive Construction of National Identity, Edinburgh University Press, Edinburgh.

Wodak R. (2001), The Discourse-Historical Approach, in: Methods of Critical Discourse Analysis, eds. R. Wodak, M. J. Meyer et al., Sage, London.

\title{
Tożsamość arystokracji polskiej jako dyskurs ideologiczny: krytyczna analiza dyskursu
}

\begin{abstract}
Streszczenie
Na przelomie XX i XXI wieku za dominujące podejście w badaniach tożsamości narodowej można uznać krytyczną analizę dyskursu (critical discourse analysis - CDA), zakładająca, że naród jest wyobrażalnym społeczeństwem utrzymywanym w sposób dyskursywny. Trzeba ponadto dodać, iż CDA lamie dotychczasowe wyobrażenie o dychotomii między narodami politycznymi a kulturalnymi, ponieważ uważa, że jest ona konstruktem zbudowanym przez rywalizujące partie narodowe. Jeżeli większość badaczy wykorzystujących CDA ogranicza swoje podejścia do nowoczesnego kontekstu XX wieku, należy postawić pytanie, czy i w jakim stopniu można stosować owe metody w badaniach przednowoczesnych tożsamości narodowych. Wyjaśnienie tej kwestii należy uznać za główny cel niniejszej pracy. Jako odpowiedni przykład wybrano polski naród szlachecki, gdyż jego elity zmuszone byly do refleksji nie tylko nad utratą własnej państwowości i z nią związanej kwestii przyszlego rozwoju, lecz także nad przyczynami własnego niepowodzenia. Analiza starć pomiędzy konserwatywnymi interpretacjami narodu w XIX wieku powinna bowiem rozstrzygnąć, kto byl przez ich pryzmat uważany za Polaka oraz w jakim stopniu owa tożsamość narodowa wywodziła się ze wzorców ideologicznych i dyskursywnych.
\end{abstract}

Słowa kluczowe: krytyczna analiza dyskursu, polska tożsamość, konsrwatyzm, nacjonalizm, konstruktywizm 
